\title{
THE INFLUENCE OF ALTERED HOMEOSTASIS ON MAMMARY GLAND RUBIDIUM CONCENTRATIONS IN DOGS
}

\author{
Ewa M. Skibniewska, ${ }^{1}$ Michał Skibniewski, ${ }^{2}$ \\ Tadeusz Kośla ${ }^{1}$ \\ ${ }^{1}$ Department of Biology of Animal Environment \\ ${ }^{2}$ Department of Morphological Sciences \\ Warsaw University of Life Sciences- SGGW
}

\begin{abstract}
Rubidium is an alkaline metal with exceptional chemical activity. Together with lithium, sodium, potassium and cesium, it belongs to group I of the periodic table of elements.

The aim of this study was to provide data on the rubidium content in normal mammary gland tissue and adenocarcinomas and to elucidate the effects of altered homeostasis on this element in the course of mammary gland neoplastic disease in dogs. The investigation was performed to confirm the hypothesis put forward in human research that this metal is cumulated in neoplastic tumours of the mammary gland.

The research material included post mortem collected healthy mammary glands of bitches and mammary gland neoplastic tumours obtained during routine surgical treatments as well as during necropsies. The content of rubidium was determined by the inductively coupled plasma mass spectrometry (ICP-MS) method.

The highest rubidium content was observed in the tissues with neoplastic lesions, where it averaged $10.72 \mathrm{mg} \mathrm{kg}^{-1}$ wet mass. In the healthy tissues, the content of this metal was on a much lower level. The mean rubidium concentration in mammary glands without pathological changes was $1.91 \mathrm{~m} \mathrm{~kg}^{-1}$ wet mass. The statistical analysis showed a significant difference $(P=0.01)$ in the rubidium content between the investigated groups. Higher rubidium concentrations were observed in the tissues with neoplastic lesions. This phenomenon is similar to disturbances of the ionic balance observed in the case of breast cancer in women.
\end{abstract}

Key words: rubidium, dogs, mammary glands, health, tumours.

dr hab. Ewa M. Skibniewska, Department of Biology of Animal Environment, Warsaw University of Life Sciences SGGW, Ciszewskiego 8, 02-786 Warsaw, Poland, e-mail: ewa_skibniewska@sggw.pl, Fax: +48 225936611 


\title{
WPŁYW ZABURZONEJ HOMEOSTAZY NA ZAWARTOŚĆ RUBIDU \\ W GRUCZOLE SUTKOWYM SUK
}

\begin{abstract}
Abstrakt
Rubid jest metalem alkalicznym o wyjątkowej aktywności chemicznej. Podobnie jak lit, sód, potas i cez, należy do I grupy układu okresowego pierwiastków.

Celem badań było dostarczenie danych na temat zawartości rubidu w zdrowych gruczołach sutkowych samic psów oraz $\mathrm{w}$ gruczolakorakach w celu zrozumienia wpływu zaburzeń homeostazy na kumulację tego pierwiastka w przebiegu nowotworów. Badania prowadzono w celu potwierdzenia hipotezy wysuniętej na podstawie badań dotyczących wzrostu zawartości tego metalu w guzach nowotworowych gruczołu sutkowego kobiet. Materiał badawczy obejmował pośmiertnie zebrane zdrowe gruczoły sutkowe suk oraz wycinki guzów nowotworowych gruczołu sutkowego uzyskane podczas rutynowych zabiegów chirurgicznych. Zawartość rubidu określono za pomoca metody ICP-MS. Najwyższa jego koncentrację stwierdzono w tkankach ze zmianami nowotworowymi, w których średnia zawartość tego pierwiastka wynosiła $10,72 \mathrm{mg} \mathrm{kg}^{-1}$ świeżej masy. W zdrowych tkankach wykazano znacznie mniejszą zawartość rubidu, średnio $1,91 \mathrm{mg} \mathrm{kg}^{-1}$ świeżej masy. W analizie statystycznej stwierdzono istotną różnicę $(p=0,01)$ między badanymi grupami. Wyższe zawartości rubidu zaobserwowano w tkankach dotkniętych procesem nowotworzenia. Zjawisko to ma podobny charakter do zaburzeń równowagi jonowej występującej w przebiegu nowotworów sutka u kobiet.
\end{abstract}

Słowa kluczowe: rubid, psy, gruczoły sutkowe, zdrowie, guzy.

\section{INTRODUCTION}

Rubidium is an alkaline metal with exceptional chemical activity. Together with lithium, sodium, potassium and cesium, it belongs to group I of the periodic table of elements; regarding its occurrence in the earth's crust, rubidium is the $16^{\text {th }}$ most frequent element (Selin, TeEyasoontranont 1991). It is quite common in the environment and is able to replace potassium in metabolic reactions, which may cause disturb their course. The role of rubidium in to animals has not been finally determined. The studies conducted to date indicate that it may be essential; however, there is a small margin between its possible required concentration and its toxic effect on an organism (Angelov 1994, ANKe, Angelov 1995, Kośla et al. 2002, Milman et al. 2006, Skibniewska et al. 2012). This element is assimilated very quickly and effectively, but excreted very slowly (SCHÄFER, ForTH 1983). The tissues in which the process of carcinogenesis takes place have a special predilection for the accumulation of rubidium (Rizk, Sky-Peck 1983, Drake, Sky-Peck 1989, TAMANo et al. 2002). In studies conducted on mice suffering from experimentally induced cancer, a 10-fold increase of the level of rubidium in the tumour tissue as compared to healthy tissues was found (FELDSTEIN et al. 1998). An analogously high content of this element was recorded in malignant breast tumours in women (MAJEWSKA et al. 1998). 
Only few publications dedicated to the rubidium content in malignant tumours in animals have been published until now. The aim of the current research was to expand our knowledge on the content of rubidium in the tissue of mammary glands of dogs and the changes in its concentration, depending on ongoing carcinogenesis processes. Also, an attempt was made to verify the hypothesis which assumes that during carcinogenesis in dogs, phenomena similar to those described in people could appear, e.g. disturbance of homeostasis causing an increase of concentrations of certain elements in tumour tissues.

\section{MATERIAL AND METHODS}

The research material was divided into two groups (Table 1). The first one consisted of post mortem collected bitch mammary glands $(n=10)$ without tumour lesions. The second group included neoplastic tumours $(n=30)$ collected during surgical operations, tumours derived from bitch subjected to euthanasia due to advanced cancer disease and from animals dead because of mammary gland cancer. Because of the character of the study which required collection of post mortem tissues and tissues obtained from routine mastectomy procedures performed in veterinary clinics, no consent of ethical commission was necessary according to the Polish law. The tissues which revealed dysplasia and hyperplasia were excluded from the study. The specific nature of the research meant that the analysis covered only tumours with dimensions allowing collection of a representative sample for determination of the elemental content as well as histopathological examination. Due to a high morphological diversity of tumours of mammary glands in bitches, the study was conducted on a group of neoplasms of the epithelial origin which were isolated on the grounds of histopathological analysis. This group consisted of adenocarcinomas. The effect of animal age on the tumours tissue distribution of rubidium was also determined in the investigated group. Dogs were divided into the following age categories: 5-9 years of age, $10-13$ years and 14-16 years.

The control group consisted of mammary glands collected from animals with documented origin which died during various incidents. The animals from that group were not in the lactation stage. The mean age of the examined healthy animals was 7 years, lower than in the group of dogs with neoplastic changes, where it reached 11 years. In each case, $c a 5 \mathrm{~g}$ of fresh tissues were obtained and the collected material was dissected appropriately with a plastic blade. After preservation in $10 \%$ formaldehyde, fragments of tissues were subjected to pathomorphologic examination; the remaining part of each sample was kept frozen in plastic bags until determinations of the content of the elements. 
Characteristics of the dogs studied

\begin{tabular}{|l|c|c|}
\hline \multicolumn{1}{|c|}{ Item } & Control group & Neoplastic group \\
\hline Number of females & 10 & 30 \\
\hline Mean age (years) & 7 & 11 \\
\hline Range of age females (years) & $4-10$ & $5-16$ \\
\hline
\end{tabular}

Before commencing the chemical analyses, the tissues were homogenized and then $0.5 \mathrm{~g}$ of every sample was placed in a Teflon vessel and mineralized in nitric acid under pressure in a microwave. The content of rubidium was determined by the inductively coupled plasma mass spectrometry (ICP-MS) method, with relation to reference material. Statistical calculations of the data was performed using Statistica Pl, version 10 (Statsoft Inc.). Because variables were not normally distributed, nonparametric tests were used for statistical analyses. Dependences of the rubidium concentration associated with the impact of the health state and age were examined using the Kruskal-Wallis $W$ test. Differences were considered as significant at the levels of $P=0.05$ and $P=0.01$. All data were expressed as an arithmetic mean \pm standard deviation SD and median. All statistical analyses were performed on wet mass concentration.

\section{RESULTS}

The lowest value of rubidium was found in mammary glands with no visible pathologic changes, i.e. $1.91 \mathrm{mg} \mathrm{kg}^{-1}$ wet mass, constituting simultaneously the control group, whereas the highest value was recorded in tumours of the epithelial origin $\left(10.72 \mathrm{mg} \mathrm{kg}^{-1}\right.$ wet mass $)$. The presence of a highly significant difference $(P=0.01)$ between the group of epithelial originated tumours and control group was recorded (Table 2).

Detailed analysis of the interaction between age and rubidium content in adenocarcinomas (Figure 1.) showed that there was a statistically significant difference between animals from group 10-13 years and 14-16 years. The highest average content of $13.3 \mathrm{mg} \mathrm{kg}-1$ of rubidium was observed in individuals from the group 10-13-year-old. It was almost 2-fold higher compared to content of this metal in the oldest females aged 14-16 years. In general, rubidium concentrations increased from the age of 5 to 13 years, and then decreased to $>14$ years. 
Table 2

Statistical distribution of parameters for rubidium concentration ( $\mathrm{mg} \mathrm{kg}^{-1}$ wet mass) in the mammary glands tissues without neoplastic lesions and with adenocarcinomas

\begin{tabular}{|l|c|c|}
\hline Statistical parameters & $\begin{array}{c}\text { Healthy mammary } \\
\text { glands }\end{array}$ & Adenocarcinomas \\
\hline Group size $(n)$ & 10 & 30 \\
\hline Arithmetic mean & $1.91 A$ & $10.72 A$ \\
\hline Standard deviation & 1.97 & 5.79 \\
\hline Lower quartile (25\%) & 1.06 & 6.07 \\
\hline Median & 1.46 & 8.73 \\
\hline Upper quartile (75\%) & 1.65 & 14.86 \\
\hline
\end{tabular}

$A$ - statistically significant differences between the groups at $P \leq 0.01$

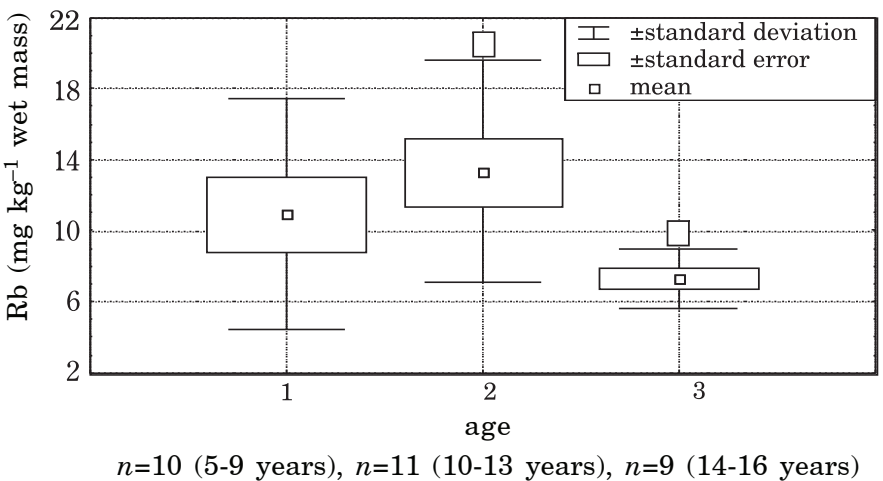

*statistically significant differences between the groups at $P=0.05$

Fig. 1. Effect of age on rubidium concentration in adenocarcinomas; data are expressed as arithmetic means, standard deviation and standard error

\section{DISCUSSION}

The chance to understand the role of mineral elements in human and animal health is created by the technological progress, which has helped to improve the quality of analysis of bioelements in tissues. Analytical techniques demonstrate many types of activity in organisms of humans as well as animals. They include, inter alia: structural i.e. inorganic function, electrochemical, and catalytic activities and other phenomena, unknown before, as well as mixed functions (Bowen 1988). 
Many observations indicate that various metals play a catalytic role in oxidative damage of biological macromolecules (EBRAHIM et al. 2007, NAGA-RAJU et al. 2006). Cancer is a complex, multi-factor disease. Despite the primary role of such environmental carcinogens such as radiation, viruses and chemical compounds, the formation and development of tumours is induced by many secondary factors. Breast cancer is a hormone-dependent cancer; mineral elements act here by mediation of various mechanisms on the cellular and sub-cellular level (NAGA-RAJU et al. 2006, ScHAzER 1980, KANIAS et al. 1994). They may be described as interactions between elements and hormones which regulate metabolism of biochemical substrates. Hence, we may and should expect the relationship between the content of mineral elements in tissue and cancer of mammary gland (EBRAHIM et al. 2007). Exposure to various carcinogens, including certain mineral elements, induces formation of free radicals, which play a significant role in development of various types of neoplasm. The discussed activity is mainly manifested in mutations and damages of DNA, leading to development of tumour (NAGA-RAJU et al. 2006, HARTwig 2000).

At already mentioned, the problem of possible indispensability of rubidium for humans and animals still remains unclear. Rubidium is found in the first group of the periodic table of elements and is present in all biological systems (FIEVE, JAMISON 1982). Alkali metals trespass biological barriers according to the following pattern: lithium substitutes sodium, whereas rubidium and cesium substitute potassium. In physiological processes, rubidium behaves like potassium and it is considered that the both discussed elements supplant each other to a great extent (ANGelov 1994, Milman et al. 2006). Until now, few studies concerning the rubidium content in human and animal tissues have been carried out. Their results suggest that its level for example in muscles of dairy cows varies within the limits of $15-26 \mathrm{mg} \mathrm{kg}^{-1}$ dry mass whereas in the liver, it is equal to $25-38 \mathrm{mg} \mathrm{kg}^{-1}$ dry mass (KośLA et al. 2002). In the respective studies concerning the content of rubidium in human liver it was found in the concentration of $7 \mathrm{mg} \mathrm{kg}^{-1}$ fresh mass of the organ, on average, which corresponds to ca $24 \mathrm{mg} \mathrm{kg}^{-1}$ dry mass. Other results suggest that it is equal to $17 \mathrm{mg} \mathrm{kg}^{-1}$, on average. Therefore, these values are similar to the data concerning animals. Also, no statistically significant differences in the rubidium level depending on climatic zones inhabited by different human populations were found: e.g., the content of rubidium in the liver of native Danish people was similar as that one found in the Inuit who live in Greenland (Milman et al. 2006). In the studies concerning the presence of mineral elements in mammary glands of humans, it was found that the content of rubidium increased in the tissues subject to the process of carcinogenesis; however, values reported by different authors are divergent. NAGA-RAJU et al. (2006) observed that the mean rubidium content in breast cancer was $22.27 \mathrm{mg} \mathrm{kg}^{-1}$ dry mass of tissue and in healthy tissues, it amounted to $12.45 \mathrm{mg} \mathrm{kg}^{-1}$; therefore, the level of rubidium in cancerous tumours was almost twice as high as in the healthy 
tissues. Both discussed groups differed significantly statistically. Similar relationships were also reported by Hoong et al. (1993). Somewhat different results were obtained by EBRACHIM et al. (2007) and GARG et al. (1990). The mentioned authors found an increased level of rubidium in breast cancers as compared to the tissues without those lesions, but it was not as spectacular as in the studies of other research teams. On the other hand, there is lack of respective data concerning the content of rubidium in mammary gland tumours of carnivorous animals. The elaborations concerning the daily intake of the discussed element by the representatives of the mentioned animal species are unavailable. It was revealed that the daily rubidium intake in humans varied within the limits of 1-5 mg (ANGELOv 1994). In own studies on the tissue of mammary gland which was not subject to carcinogenesis, the average rubidium content was equal to $1.91 \mathrm{mg} \mathrm{kg}^{-1}$ wet mass of the organ, which approximately corresponds to $6.7 \mathrm{mg} \mathrm{kg}-1$ dry mass. The highest rubidium level was recorded in adenocarcinomas. It equalled $14.14 \mathrm{mg} \mathrm{kg}^{-1}$ wet mass of the organ, which translates to about $50 \mathrm{mg} \mathrm{kg}^{-1}$ dry mass i.e. the level which already determines the border between microand macroelements in tissues because - according to the universally adopted criteria - the elements which occur physiologically in a concentration above $0.01 \mathrm{wt} \%$, that is above $50 \mathrm{mg} \mathrm{kg}^{-1}$ dry mass of tissue. are recognized as macroelements (ANDREws et al. 2004, LewińsKA-PREISS 2011). The very high concentration which was observed herein may be the evidence of extreme insufficiency of homeostatic processes in the examined tissue.

\section{CONCLUSIONS}

To sum up, the observed considerable accumulation of rubidium results from advancement of neoplastic changes in the mammary gland of the studied dogs. This phenomenon is similar to the disturbances of ionic balance observed in cases of breast cancer in women. Differences in the level of rubidium in the tissues of adenocarcinomas as compared to pathologically unchanged tissues may suggest a potential applicability of determinations of the discussed element as a discriminating factor.

\section{REFERENCES}

Andrews J.E., Brimblecombe P., Jickells T.D., Liss P.S., Reid B.J. 2004. An introduction to environmental chemistry. $2^{\text {nd }}$ ed. Oxford, Blackwell Science.

Angelov L. 1994. Rubidium in der Nahrungskette. Habilitation. Jena, Friedrich-Schiller Universitat.

Anke M., Angelov L. 1995. Rubidium in the food chain. Fresen. J. Anal. Chem., 352: 236-239.

Bowen H.J.M. 1988. Trace elements in biological samples. Nucl Anal Tech Med Tech Instrum Anal Chem., 8: 1-17. 
Drake II E.N., Sky-Peck H.H. 1989. Discriminant analysis of trace element distribution in normal and malignant human tissues. Cancer Res., 49: 4210-4215.

Ebrahim A.M., Eltayeb M.A.H., ShaAt M.K., Mohmed N.M.A., Eltayeb E.A., Ahmed A.Y. 2007. Study of total selected trace elements in cancerous and non-cancerous human breast tissues from Sudanese subjects using instrumental neutron activation analysis. Sci. Total Environ., 383: 52-58.

Feldstein H., Cohen Y., Shenberg C., Klein A., Kojller M., Maenhaut W., Cafmeyer J., Cornelis R. 1998. Comparison between levels of trace elements in normal and cancer inoculated mice by XRF and PIXE. Biol. Trace Elem. Res., 61(2): 169-180.

Fieve R.R., Jamison K.R. 1982. Rubidium: overview and clinical perspectives. Mod. Probl. Pharmacopsychiat., 18: 145-163.

Garg A.N., Weginwar R.G., Sagdeo V. 1990. Minor and trace elemental radiochemical neutron activation analysis. Biol. Trace Elem. Res., 26-27: 485-496.

Hartwig A. 2000. Recent advances in metal carcinogenicity. Pure. Appl. Chem., 72: 1007-1014.

Hoong N.G.K., Bradley D.A., Looi L.M., Mahmood C.S., Khaik A. 1993. Differentiation of elemental composition of normal and malignant breast tissue by instrumental neutron activation analysis. Appl. Radiat. Isotopes, 44: 511-516 .

Kanias G.D., Kouri E., Arvanti H., Karoiosifidi H., Kouneli S. 1994. Trace element content in breasts with fibrocystic disease. Biol. Trace Elem. Res., 43: 363-370.

Kośla T., Skibniewska E., Dębski B., Urbańska-SŁomka G. 2002. Rubidium in the trophic chain: soil-plants-animals. Trace Elem. Electrol., 19: 171-176.

Lewińska-Preiss L., JabŁońska M., FabiańsKa M.J., Kita A. 2011. Bioelements and mineral matter in human livers from the higly industrialized region of the Upper Silesia Coal Basin (Poland). Environ. Geochem. Health, 33: 595-611.

Majewska U., Braziewicz J., Banaś D., Kubala-Kukuś A., Goźdź S., Pajek M., Smok J., Urbaniak A. 1998. An elemental correlation study in cancerous breast tissue by total reflection $X$ ray fluorescence. Biol. Trace Elem. Res., 60(1-2): 91-100.

Milman N., Laursen J., Byg K.E., Pedersen S., Mulvad G. 2006. Rubidium content in autopsy liver tissue samples from Greenlandic Inuit and Danes measured by X-ray fluorescence spectrometry. J. Trace Elem. Med. Biol., 20: 227-232.

Naga-Raju G.J., Sarita P., Ravi-kumar M., Ramana-murty G.A.V., Reddy B.S., Lakshminarayana S., Vijavan V., Rama-lakshmi P.V.B., Gavarasana S., Bhuloka-Reddy S. 2006. Trace element correlation study in malignant and normal breast tissue by PIXE technique. Nucl. Inst. \& Meth. Phys. Res., 247: 361-367.

RIZK S.L., Sky-PECK H.H. 1984. Comparison between concentrations of trace elements in normal and neoplastic human breast tissue. Cancer Res., 44:5390-5394.

Schäfer S.G., Forth W. 1983. Excretion of metals into the rat intestine. Biol. Trace Elem. Res., 5: 205-217.

SCHRAUZER G.N. 1980. The role of trace elements in the etiology of cancer. Trace Elem. Anal. Chem. Med. Biol., 1: 183-198.

Selin E., Teeyasoontranont V. 1991. Rubidium: a companion of potassium or an essential trace element of its own. Beitr. Infusionsther., 27: 86-103.

Skibniewska E.M, Kośla T., Skibniewski M. 2012. Evaluation of rubidium contents in organs of bitches (Canis lupus f. familiaris). Bull. Vet. Inst. Pulawy, 56(3): 385-388.

Tamano H., Enomoto S., Oku N., Tareda A. 2002. Preferential uptake of zinc, manganese, and rubidium in rat brain tumor. Nucl. Med. Biol., 29: 505-508. 